\section{Birth cohort differences in anthropometric measures in the older elderly: the Bambuí Cohort Study of Aging (1997 and 2008)}

\author{
Diferenças de coorte de nascimento nas medidas \\ antropométricas de idosos mais velhos: Estudo \\ de Coorte de Idosos de Bambuí (1997 e 2008)
}

Aline Dayrell Ferreira Sales 1
Cibele Comini César 1
Maria Fernanda Lima-Costa ${ }^{2}$
Waleska Teixeira Caiaffa ${ }^{1}$

\footnotetext{
1 Faculdade de Medicina, Universidade Federal de Minas Gerais, Belo Horizonte, Brasil.

2 Núcleo de Estudos em Saúde Pública e Envelhecimento, Fundação Oswaldo Cruz/Universidade Federal de Minas Gerais, Belo Horizonte, Brasil.

Correspondence A. D. F. Sales Observatório de Saúde Urbana de Belo Horizonte, Faculdade de Medicina, Universidade Federal de Minas Gerais

Av. Antônio Abrahão Caram 540, apto. 202,

Belo Horizonte, $M G$

31275-000, Brasil.

dayrellferreira@yahoo.com.br
}

\begin{abstract}
The aim of this study was to evaluate the effect of birth cohort on nutritional status among older elderly (71-81 years old) from the Bambui Cohort Study of Aging, conducted in Brazil in 1997 and 2008. We compared the two birth cohorts 1916-1926 (older cohort) and 1927-1937 (recent cohort) - considering body mass index (BMI = weight/height ${ }^{2}$ ), waist circumference (WC) and prevalence of overweight $\left(B M I \geq 27 \mathrm{~kg} / \mathrm{m}^{2}\right)$. BMI $(\beta=0.09,95 \% C I: 0.04,0.15)$ and prevalence of overweight $(P R=1.02 ; 95 \% C I: 1.01 ; 1.03)$ were higher in the recent cohort than the earlier cohort, regardless of sex and schooling. No difference was observed in WC. Stratified by sex, similar overall trends were observed for men, and WC was higher in the recent cohort. Among women there was no difference in BMI and overweight, but WC was lower in the recent cohort. The cohort effect was greater among older men and, in the near future, may result in greater prevalence of overweight in this group.
\end{abstract}

Nutritional Status; Anthropometry; Aged; Cohort Studies

\section{Introduction}

Brazil is aging rapidly. In 1950, with 2.1 million older adults, it ranked $16^{\text {th }}$ in the world. By 2025 it is expected to stand sixth, with 31.8 million older adults, i.e., in 75 years the population over 60 years old will increase fifteen times, while the overall population will grow five-fold 1 . While the population of elderly can be seen to grow steeply (2-4\% per year), the younger population is growing more slowly 2 . This rapid demographic transition signals a need to know more about the aging process, including nutritional state, among Brazilians 3,4. Population-based studies evaluating nutritional state among the elderly in Brazil are rare and limited to cross-sectional studies 5,6,7.

Generally speaking, overweight and obesity are reaching epidemic proportions worldwide. Rapidly increasing prevalence of overweight (body mass index $-\mathrm{BMI} \geq 25 \mathrm{~kg} / \mathrm{m}^{2}$ ) has been observed in many developed and developing countries, including Brazil. In the 1970s, prevalence of overweight in adults ( $\geq 18$ years old) was $16.7 \%$ among men and $25.6 \%$ among women, rising in 1989 to $25.4 \%$ and $38.2 \%$, respectively 8 . A telephone survey conducted recently among Brazilian adults revealed that prevalence of overweight has continued to grow, rising from $42.7 \%$ in 2006 to $44.2 \%$ in 2008 9,10.

Flegal et al. 11 argued that explanations of the increasing prevalence of obesity must first consider overall social conditions, as well as cul- 
tural changes in the population. The hypothesis that historical changes take place, probably as a result of cultural, behavioral and environmental changes, can be sustained if consistent change is evidenced by birth cohort studies 12 .

Cohort analysis is used to identify risks in specific birth cohorts, by furnishing information vital both to public health surveillance and to identifying the etiology and time trends of many diseases 13 . A birth cohort groups individuals by year of birth, thus furnishing a single series from which it is possible to identify how the experiences of people born at one point in time differ from those born in a different period ${ }^{14}$. When what is involved is an effect of age, then the changes in disease rates occur independently of birth cohort and calendar time 15 . The variations are thus associated with chronological age, and caused by physiological changes, accumulated social experiences, changes in status and/or represent lifecourse developmental changes 16 .

Given the scarcity of studies of the elderly population and the historical rise in overweight and obesity rates, this study examines whether there is a birth cohort effect on anthropometric measurements - BMI, overweight and waist circumference (WC) - in a population of older elderly resident in the community.

\section{Methods}

\section{Data source and population studied}

This study used data on the population-based cohort of older adults in Bambuí, Minas Gerais, Brazil, the details of which are available in previous publications 17,18 .

The cohort baseline was established in 1997. All residents of Bambuí city (population 15,000), 60 years old or older on 1 January 1997 , were eligible for the study. Of the 1,742 residents in the age group studied, $92.2 \%(n=1.606)$ participated in the baseline, which comprised interviews and biological measurements (including anthropometric evaluation, hematological and biochemical examinations, and measurement of arterial pressure). Baseline participants were monitored annually by interview and death certificate review. Other procedures, including anthropometric evaluation, were repeated in 2000 , 2002 and 2008. In the first ten years of followup, 641 participants died and $6.9 \%$ were lost to follow-up 17,18.

All participants in the cohort aged 71-81 years at the baseline (1997), i.e., born between 1916 and 1926 (older cohort), and all participants in that

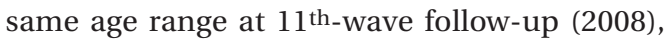

i.e., born between 1927-1937 (recent cohort), were selected for the present study.

\section{Anthropometric measurements}

Nutritional status was gauged from anthropometric measurements. For the present study, weight, height and WC were considered. All anthropometric measurements were taken three times by a trained team; for purposes of analysis, the mean was considered. The weight and height measurements were used to calculate BMI (weight/height ${ }^{2}$ ). Overweight in the older adults was defined as BMI $\geq 27 \mathrm{~kg} / \mathrm{m}^{2}$, as recommended by the Nutrition Screening Initiative 19 and Lipschitz 20 .

\section{Statistical analysis}

Student t-tests (for continuous variables) and Pearson chi-square test (for categorical variables) were used to examine differences in age, sex, years of schooling and anthropometric measurements between the two cohorts. Regression models were adjusted for the comparisons between the two birth cohorts in terms of anthropometric variables. For the continuous variables (BMI and WC), a linear regression model was adjusted, and the coefficients and their respective 95\% confidence intervals were obtained. For the variable "overweight", the analysis was based on prevalence ratio (PR) and robust confidence interval $(95 \% \mathrm{CI})$ estimated by Poisson regression. Birth cohort was considered an independent variable, with the older cohort (1916-1926) considered the reference category, and the recent cohort (1927-1937), the exposure category. Initially, the analyses were performed for all participants, and the model was adjusted for sex and years of schooling. Subsequently, stratified analyses were performed by sex, and the model was adjusted for years of schooling.

A graphic analysis of the prevalence of overweight was conducted, considering year of birth and age to ascertain secular trends and potential birth cohort effect patterns. Curves were smoothed using the lowess command of R software, version 2.10.2 (The R Foundation for Statistical Computing, Vienna, Austria; http://www.rproject.org), which uses the locally weighted polynomial regression technique.

All analyses were performed using R software (version 2.10.2).

\section{Ethical considerations}

The population-based cohort study of older adults from Bambuí was approved by the Ethics 
Research Committee of the Oswaldo Cruz Foundation (Fundação Oswaldo Cruz), Rio de Janeiro, Brazil. All participants signed a Declaration of Free, Informed Consent, which was renewed at all years of follow-up.

\section{Results}

Of the 492 participants of the 1997 survey who were 71-81 years old, anthropometric measurements were available for 459 (93.3\%), who were included in the present study. Of the 657 survivors of the cohort in 2008, in the same age range, 576 (97.6\%) participated. In both 1997 and 2008, participants and non-participants (including losses from incomplete data in 1997, and loss to follow-up and incomplete data in 2008) were similar in terms of sex $(p=0.179$ and $p=0.886$, respectively), age ( $\mathrm{p}=0.170$ and $\mathrm{p}=0.070$, respectively) and schooling ( $\mathrm{p}=0.256$ and $\mathrm{p}=0.364$, respectively).

The socio-demographic profile of the study participants in $1997(\mathrm{n}=459)$ and $2008(\mathrm{n}=576)$ was similar in terms of age $(75.1 \pm 3.2$ years $v s$. $75.2 \pm 3.1$ years; $\mathrm{p}=0.741)$ and $\operatorname{sex}(59.6 \% v s$. $63.4 \%$ women; $\mathrm{p}=0.177$ ). They differed only in years of schooling: in 1997 a greater proportion of individuals $(36.7 \% v s .27 .4 \% ; \mathrm{p}=0.001)$ had no schooling ( 0 years of schooling). In the analysis stratified by sex, a greater proportion of women had no schooling in both periods (Table 1).
Distinct anthropometric profiles were identified among older adults in the same age range (71-81 years) in the two cohorts. Individuals from the more recent birth cohort had significantly higher BMI than individuals of the older cohort (1916-1926) ( $\beta=0.09$; 95\%CI: 0.04; 0.15), independently of sex and schooling. The former also displayed a higher prevalence of overweight than the latter, independently of sex and schooling (PR $=1.02$; 95\%CI: $1.01 ; 1.03)$. Mean waist circumference was similar in the two cohorts $(\beta=-0.05$; 95\%CI: -0.19; 0.08) (Table 2).

Among the men, after adjustment for schooling, the recent cohort displayed higher BMI than the older cohort ( $\beta=0.16$; 95\%CI: $0.09 ; 0.24)$; in the same direction, the recent cohort displayed greater prevalence of overweight $(\mathrm{PR}=1.06$; 95\%CI: $1.03 ; 1.10)$, and mean waist circumference ( $\beta=0.40$; 95\%CI: $0.18 ; 0.63$ ) (Table 2 ).

Among the women, no differences were observed between the two cohorts as regards mean BMI ( $\beta=0.05$; 95\%CI: $-0.02 ; 0.12$ ) and prevalence of overweight (PR = 1.00; 95\%CI: 0.98; 1.02). Contrary to what was observed among the men, waist circumference among women was smaller in the more recent cohort than in the older cohort, independently of schooling $(\beta=-0.34 ; 95 \% \mathrm{CI}$ : -0.51 ; -0.16) (Table 2).

As can be seen in Figure 1a, there appears to have been an age effect on prevalence of overweight among individuals of the older cohort, i.e., prevalence of overweight was observed to decline

Table 1

Socio-demographic characteristics of study participants, by birth cohort. The Bambuí Cohort Study of Aging, 1997-2008.

\begin{tabular}{|c|c|c|c|}
\hline \multirow[t]{3}{*}{ Sample/Period } & \multicolumn{3}{|c|}{ Variables } \\
\hline & Age & Sex & Schooling \\
\hline & Mean \pm standard deviation & \% women & $\%$ with 0 years' schooling \\
\hline \multicolumn{4}{|l|}{ Total sample } \\
\hline $1997(n=459)$ & $75.1 \pm 3.2$ & 59.6 & 36.7 \\
\hline $2008(n=576)$ & $75.2 \pm 3.1$ & 63.4 & 27.4 \\
\hline$p$-value * & 0.741 & 0.177 & 0.001 \\
\hline \multicolumn{4}{|l|}{ Men } \\
\hline $1997(n=182)$ & $75.1 \pm 3.3$ & - & 34.3 \\
\hline $2008(n=210)$ & $74.8 \pm 2.9$ & - & 23.0 \\
\hline$p$-value * & 0.349 & - & 0.008 \\
\hline \multicolumn{4}{|l|}{ Women } \\
\hline $1997(n=277)$ & $75.1 \pm 3.1$ & - & 38.2 \\
\hline $2008(n=366)$ & $75.4 \pm 3.1$ & - & 30.0 \\
\hline$p$-value * & 0.278 & - & 0.020 \\
\hline
\end{tabular}

* $p$-value results from the comparison between study periods ( $t$-test and chi-square test for differences between means and frequencies, respectively). 
Anthropometric profile by birth cohort. The Bambui Cohort Study of Aging, 1997-2008.

\begin{tabular}{|c|c|c|c|}
\hline \multirow[t]{2}{*}{ Sample/Birth cohort } & \multicolumn{3}{|c|}{ Variables } \\
\hline & BMI & WC & Overweight (BMI $\geq 27 \mathrm{~kg} / \mathrm{m}^{2}$ ) \\
\hline \multicolumn{4}{|l|}{ Total sample } \\
\hline $1916-1926(n=459)$ & $24.4 \pm 4.9$ & $90.8 \pm 11.5$ & 28.9 \\
\hline $1927-1937(n=576)$ & $25.6 \pm 5.2$ & $90.4 \pm 12.6$ & 36.6 \\
\hline Coefficient *,** & $0.09 * \star \star$ & -0.05 & - \\
\hline$P R * *$, \# & - & - & $1.02 \#$ \\
\hline $95 \% \mathrm{Cl}$ & $0.04 ; 0.15$ & $-0.19 ; 0.08$ & $1.01 ; 1.03$ \\
\hline \multicolumn{4}{|l|}{ Men } \\
\hline $1916-1926(n=182)$ & $22.5 \pm 4.7$ & $88.6 \pm 11.5$ & 16.0 \\
\hline $1927-1937(n=210)$ & $24.9 \pm 4.3$ & $93.4 \pm 12.8$ & 32.7 \\
\hline Coefficient *,\#\#\# & $0.16 * \star \star$ & $0.40 * \star \star$ & - \\
\hline PR \#,\#\# & - & - & 1.06 *** \\
\hline $95 \% \mathrm{Cl}$ & $0.09 ; 0.24$ & $0.18 ; 0.63$ & $1.03 ; 1.10$ \\
\hline \multicolumn{4}{|l|}{ Women } \\
\hline $1916-1926(n=277)$ & $25.3 \pm 5.2$ & $92.2 \pm 11.5$ & 37.3 \\
\hline $1927-1937(n=366)$ & $26.0 \pm 5.6$ & $88.6 \pm 12.2$ & 38.9 \\
\hline Coefficient *,\#\#\# & 0.05 & $-0.34 * \star \star$ & - \\
\hline PR \#,\#\# & - & - & 1.00 \\
\hline $95 \% \mathrm{Cl}$ & $-0.02 ; 0.12$ & $-0.51 ;-0.16$ & $0.98 ; 1.02$ \\
\hline
\end{tabular}

BMI: body mass index; PR: prevalence ratio; WC: waist circumference; $95 \% \mathrm{Cl}$ : $95 \%$ confidence interval.

Note: the 1916-1926 birth cohort was considered the reference group.

* Estimated by linear regression;

** Adjusted by sex and years' schooling;

${ }^{* * *} p \leq 0.001$

\# Estimated by Poisson regression;

$\#$ \# $\leq$ 0.05;

\#\# Adjusted for years' schooling.

with increasing age. In the more recent cohort, however, the influence of age was not perceived. Comparing the two cohorts, the smoothed curve revealed a trend where prevalence of overweight was greater in the recent cohort than in the older cohort at all ages, and this difference increased at more advanced age ( $>78$ years old).

When stratified by sex, prevalence of overweight behaved differently, with age, among men and women. With increasing age, prevalence of overweight increased among men, but declined among women (Figures $1 \mathrm{~b}$ and 1c). The birth cohort effect was clear among men, given that prevalence of overweight was greater among those born in the more recent cohort (Figure 1b). Among the women, this effect was not clearly observable (Figure 1c).

\section{Discussion}

Anthropometric profiles were observed to differ between older adults in the same age range (7181 years), born in different periods. Individuals in the more recent birth cohort (1927-1937) showed greater weight gain both in mean BMI and in prevalence of overweight as compared with individuals born in the older cohort (1916-1926). The effects of both birth cohort and age on anthropometric profile seem to have been greater among men than among women.

Despite the scarcity of international and Brazilian studies examining the evolution of body composition over time 5,6,7,21,22, particularly in the elderly population 23 , some comparisons can be made. The findings of this study are consistent with the literature as regards the greater prevalence of overweight and obesity among women. In both 1997 and 2008, prevalence of 
Figure 1

Graphic analysis, with curve smoothing, of age effect and birth cohort effect on prevalence of overweight. The Bambui Cohort Study of Aging, 1997-2008.

1a) Total sample $(n=1,035)$

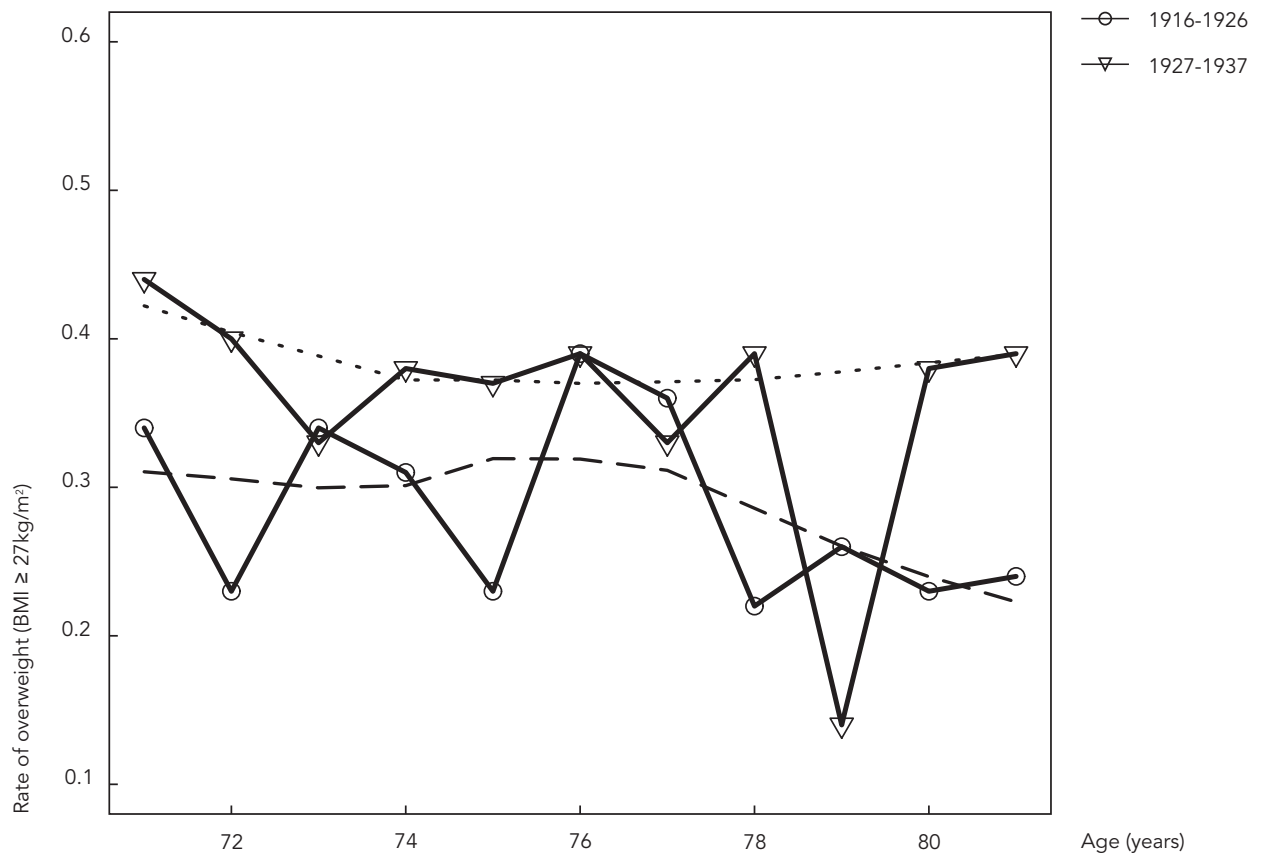

1b) Sample of men $(n=392)$

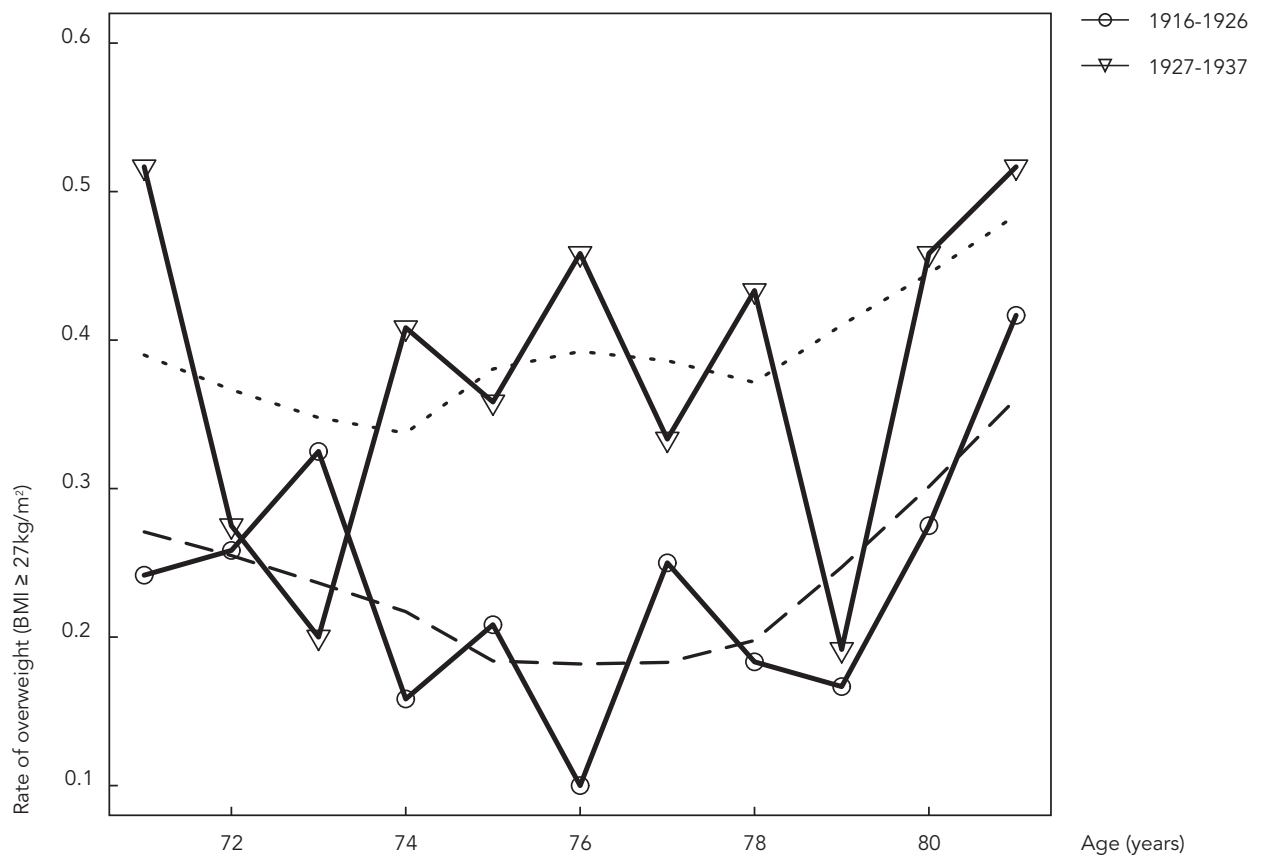

(continues) 


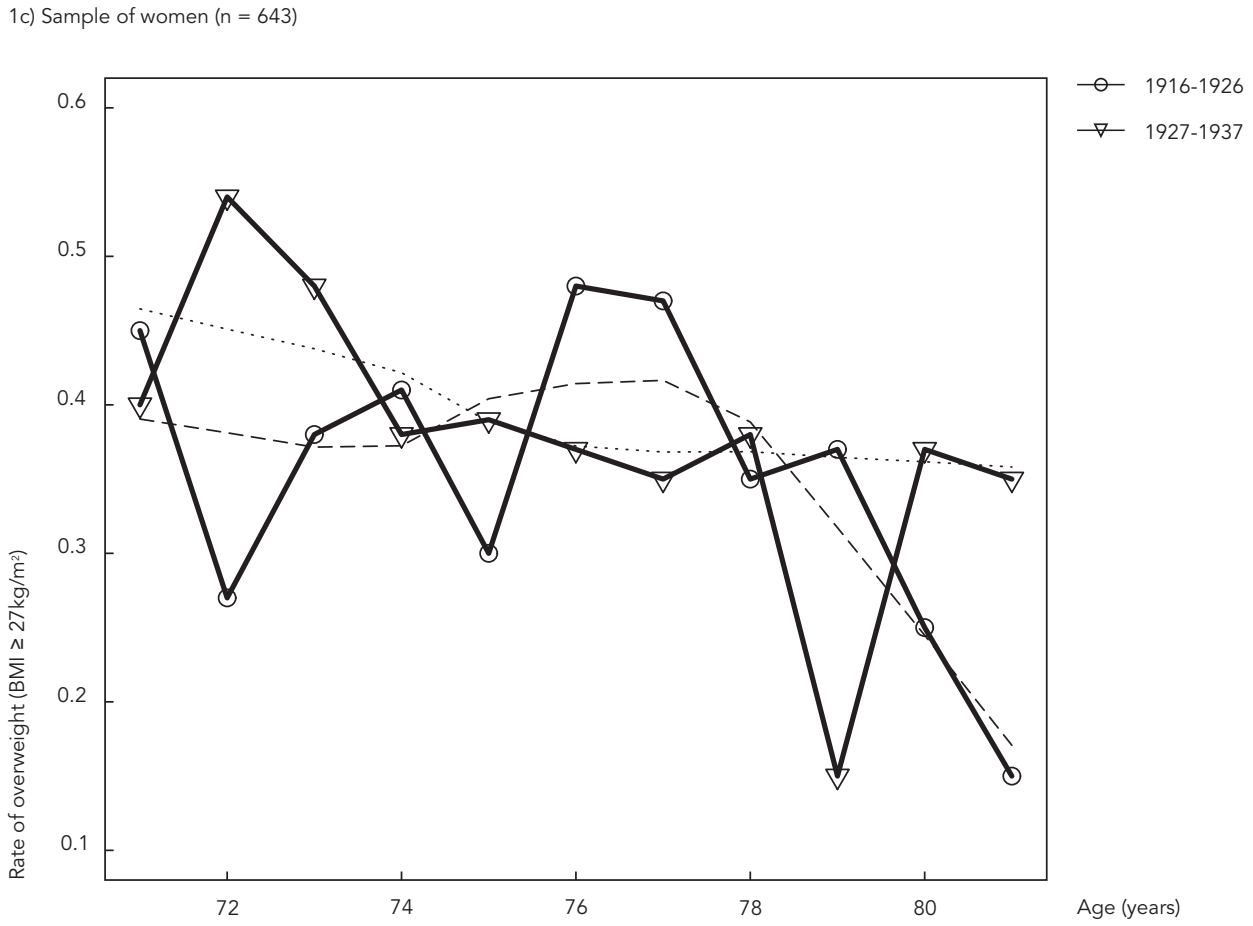

overweight (BMI $\geq 27 \mathrm{~kg} / \mathrm{m}^{2}$ ) was greater among women (37.3\% in 1997 and $38.9 \%$ in 2008) than among men in the same years (respectively, $16 \%$ and $32.7 \%$ ). Comparable prevalences were also even encountered in studies that used different classifications for overweight/obesity in older adults, such as Eiben et al. 23, which considered obesity as given by $\mathrm{BMI} \geq 30 \mathrm{~kg} / \mathrm{m}^{2}$, and Menezes \& Marucci 24 , which assessed overweight/obesity in terms of BMI percentiles.

It is argued that such differences are probably due to biological considerations relating to men's greater tendency to accumulate lean mass and, among women, relating to menopause accompanied by increased weight and adiposity ${ }^{3}$. However, although biological factors do favor weight gain, it has to be understood whether other factors - such as social conditions, environment, behavior and habits acquired over life course with changing paradigms of health and illness - have affected how the profile of nutritional status has evolved historically in a given population.

Accordingly, changing contemporary effects of the environment can be assessed by way of birth cohort effect 13 , as proposed by this study. Considering that schooling 12 and sex 23,24 are associated with nutritional status, the anthropometric profile of the study population was ascertained in two birth cohorts (1916-1926 and 1927-1937), and adjusted for sex and years of schooling.

Older adults born into the more recent cohort (1927-1937) showed a higher mean BMI and also greater prevalence of overweight. This finding matches those observed by some other authors studying secular trend towards adult obesity, who point to greater prevalence in more recent birth cohorts 13,16, and highlight even more marked increases among those born since the 1960s 16 .

The trend observed here is consistent with assertions that more recent birth cohorts tend to adapt more quickly to cultural and technological changes 16. Individuals born in 1927-1937 spent part of their childhood and adolescence in a period (the late 1940s) that was marked by major demographic, epidemiological and nutritional changes. At that stage of life, habits and behavior are strongly defined, and very often persist into adult life 25 .

Considering that the differences between birth cohorts are related to historical changes from either changing cultural, behavioral or 
environmental circumstances ${ }^{12}$, secular trends in anthropometric changes can be expected to differ by sex, given that women tend to access health services more 26 , and to change their patterns of diet and physical activity more quickly than men 27.

Stratifying by sex, it was observed that men born in the more recent cohort displayed greater mean BMI, waist circumference and prevalence of overweight than men born in the older cohort. Among the women, meanwhile, there was no difference between the birth cohorts in terms of mean BMI and prevalence of overweight, even given smaller waist circumference in the more recent cohort.

Studies examining cohort effect on nutritional status in adults present similar findings. A study in Finland on BMI trend by birth cohort demonstrated that obesity affected middle-aged men more, but had limited impact on women: from 1972 to 1997 , BMI was observed to increase 1.96 units among men and only 0.32 among women 28 . In that same direction, a study in Sweden of a population in their 70s, born between 1901 and 1930, investigating differences in anthropometric measurements among different cohorts, found higher mean weight, BMI, WC, prevalence of overweight (BMI $\geq 25 \mathrm{~kg} / \mathrm{m}^{2}$ ) and obesity (BMI $\geq 30 \mathrm{~kg} /$ $\mathrm{m}^{2}$ ) in more recent cohorts for both sexes, although the impact was greater among the men 23 . As in our study, however, other authors studying different birth cohorts have identified differences in BMI among men only 29,30.

\section{Resumo}

Este estudo avaliou o efeito de coorte de nascimento no estado nutricional de idosos de 71 a 81 anos, participantes em 1997 e 2008 da coorte de Bambuí, Minas Gerais, Brasil. Foram comparados idosos nascidos em 1916-1926 (coorte antiga) e em 1927-1937 (coorte recente), quanto ao índice de massa corporal (IMC = peso/altura 2 ), circunferência da cintura (CC) e proporção de sobrepeso (IMC $\geq 27 \mathrm{~kg} / \mathrm{m}^{2}$ ), utilizando-se modelos de regressão linear e de Poisson. Após ajustamento por sexo e anos de escolaridade, idosos da coorte recente em comparação à coorte antiga apresentaram maior
This study has advantages and limitations. The advantages include the study population base, the long time span (11 years) of the comparison, the high response rate at both data collection points (which was apparently not affected by age, sex or schooling), and the strict standardization of the measurements taken in 1997 and 2008. The main limitation of the study is its crosssectional analysis, which does not allow the evolution of anthropometric measurements in the same individuals, nor the determinants of any such changes, to be examined.

In spite of these limitations, this exploratory study addresses unprecedented questions regarding overweight trends and related measurements in a Brazilian population of older elderly. Further investigations are necessary to examine the determinants of anthropometric changes among older adults and the related sex differentials, particularly considering the historical evolution of the health-illness process in each population.

The increase in BMI is directly related to increase in morbid-mortality and worse quality of life and, in the elderly, is associated with mobility and preservation of mental state 31 . In addition, preliminary information suggests increasing prevalence of arterial hypertension and diabetes mellitus among elderly participants of the recent birth cohort ${ }^{32}$, reinforcing once again the need for further studies directed to understanding the determinants of such trends better.
IMC ( $\beta=0,09$; IC95\%: 0,04; 0,15) e maior proporção de sobrepeso ( $R P=1,02$; IC95\%: 1,01; 1,03), não se observando diferenças na CC. Entre os homens da coorte recente, foram observados aumentos do IMC, do sobrepeso e da CC. Entre as mulheres, constatou-se redução da CC. Os resultados mostram um efeito de coorte na piora das medidas antropométricas entre os homens, mas não entre as mulheres.

Estado Nutricional; Antropometria; Idoso; Estudos de Coortes 


\section{Contributors}

A. D. F. Sales participated in the article's conception; data analysis and interpretation; drafting of the article, and final approval of the version for publication. C. C. César, M. F. Lima-Costa and W. T. Caiaffa contributed to study conception and design, data analysis and interpretation, important critical review of the intellectual content, and final approval of the version for publication.

\section{Acknowledgments}

To Amanda de Souza, technical support scholar of FAPEMIG, researcher of the Urban Health Observatory, Belo Horizonte (Observatório de Saúde Urbana de Belo Horizonte. A. D. F. Sales, study scholar of CAPES (20072010) and FAPEMIG (2010); C. C. César, M. F. Lima-Costa and W. T. Caiaffa, research productivity scholars of CNPq. The Bambuí Cohort Study of Aging was funded by CNPq, FAPEMIG and FINEP.

\section{References}

1. Veras RP. Brazil is getting older: demographic changes and epidemiological challenges. Rev Saúde Pública 1991; 25:476-88.

2. Carvalho JAM, Rodríguez-Wong LL. A transição da estrutura etária da população brasileira na primeira metade do século XXI. Cad Saúde Pública 2008; 24:597-605.

3. Campos MAG, Pedroso ERP, Lamounier JA, Colosimo EA, Abrantes MM. Estado nutricional e fatores associados em idosos. Rev Assoc Med Bras 2006; 52:214-21.

4. Leite-Cavalcanti C, Rodrigues-Gonçalves MC, Rios-Asciutti LS, Leite-Cavalcanti A. Prevalência de doenças crônicas e estado nutricional em um grupo de idosos brasileiros. Rev Salud Pública 2009; 11:865-77.

5. Marucci MFN, Barbosa AR. Estado nutricional e capacidade física. In: Lebrão ML, Duarte YAO, organizers. SABE - Saúde, Bem-estar e Envelhecimento - o projeto SABE no Município de São Paulo: uma abordagem inicial. Brasília: Organização Pan-Americana da Saúde; 2003. p. 95-117.

6. Barreto SM, Passos VMA, Costa MFFL. Obesity and underweight among Brazilian elderly: the Bambuí Health and Aging Study. Cad Saúde Pública 2003; 19:605-12.
7. Mastroeni MF. Estado nutricional e consumo de macronutrientes de idosos da cidade de Joinville, SC [Doctoral Dissertation]. São Paulo: Faculdade de Saúde Pública, Universidade de São Paulo; 2004.

8. Coitinho DC, Leão MM, Recine E, Sichieri R. Condições nutricionais da população brasileira: adultos e idosos. Pesquisa Nacional sobre Saúde e Nutrição. Brasília: Instituto Nacional de Alimentação e Nutrição; 1991.

9. Moura EC, Morais Neto OL, Malta DC, Moura L, Silva NN, Bernal R, et al. Vigilância de Fatores de Risco para Doenças Crônicas por Inquérito Telefônico nas capitais dos 26 estados brasileiros e no Distrito Federal (2006). Rev Bras Epidemiol 2008; 11 Suppl 1:20-37.

10. Secretaria de Gestão Estratégica e Participativa, Secretaria de Vigilância em Saúde, Ministério da Saúde. VIGITEL Brasil 2008. Vigilância de fatores de risco e proteção para doenças crônicas por inquérito telefônico. Brasília: Ministério da Saúde; 2009.

11. Flegal KM, Carroll MD, Kuczmarski RJ, Johnson CL. Overweight and obesity in the United States: prevalence and trends, 1960-1994. Int J Obes Relat Metab Disord 1998; 22:39-47. 
12. Reynolds SL, Himes CL. Cohort differences in adult obesity in the United States: 1982-2002. J Aging Health 2007; 19:831-50.

13. Keyes KM, Utz RL, Robinson W, Li G. What is a cohort effect? Comparison of three statistical methods for modeling cohort effects in obesity prevalence in the United States, 1971-2006. Soc Sci Med 2010; 70:1100-8.

14. Allman-Farinelli MA, Chey T, Bauman AE, Gill T, James WPT. Age, period and birth cohort effects on prevalence of overweight and obesity in Australian adults from 1990 to 2000. Eur J Clin Nutr 2008; 62:898-907.

15. Zhu C, Zheng T, Kilfoy BA, Han X, Ma S, Ba Y, et al. A birth cohort analysis of the incidence of papillary thyroid cancer in the United States, 1973-2004. Thyroid 2009; 19:1061-6.

16. Reither EN, Hauser RM, Yang Y. Do birth cohorts matter? Age-period-cohort analyses of the obesity epidemic in the United States. Soc Sci Med 2009; 69:1439-48.

17. Lima-Costa MF, Firmo JOA, Uchôa E. Cohort profile: the Bambui (Brazil) Cohort Study of Aging. Int J Epidemiol 2010; [Epub ahead of print].

18. Lima-Costa MF, Firmo JOA, Uchôa E. The Bambuí Cohort Study of Aging: methodology and health profile of participants at baseline. Cad Saúde Pública 2011; 27 Suppl 3:S327-35.

19. Nutrition Screening Initiative. Incorporating nutrition screening and interventions into medical practice: a monograph for physicians. Washington DC: Nutrition Screening Initiative; 1994.

20. Lipschitz DA. Screening for nutritional status in the elderly. Prim Care 1994; 21:55-67.

21. Barbosa AR, Souza JMP, Lebrão ML, Laurenti R, Marucci MFN. Anthropometry of elderly residents in the city of São Paulo, Brazil. Cad Saúde Pública 2005; 21:1929-38.

22. Liese AD, Döring A, Hense HW, Keil U. Five year changes in waist circumference, body mass index and obesity in Augsburg, Germany. Eur J Nutr 2001; 40:282-8
23. Eiben G, Dey DK, Rothenberg E, Steen B, Björkelund C, Bengtsson C, et al. Obesity in 70-year-old Swedes: secular changes over 30 years. Int J Obesity $2005 ; 29: 810-7$.

24. Menezes TN, Marucci MFN. Antropometria de idosos residentes em instituições geriátricas, Fortaleza, CE. Rev Saúde Pública 2005; 39:169-75.

25. Lemos MCM, Dallacosta MC. Hábitos alimentares de adolescentes: conceitos e práticas. Arq Ciências Saúde UNIPAR 2005; 9:3-9.

26. Capilheira MF, Santos IS. Fatores individuais associados à utilização de consultas médicas por adultos. Rev Saúde Pública 2006; 40:436-43.

27. Monteiro CA, Benício MHD’A, Popkin BM. Preditores economicos e socioculturais para sobrepeso de mulheres brasileiras em áreas rurais e urbanas. Rev Bras Nutr Clín 2000; 15:253-60.

28. Lahti-Koski M, Jousilahti P, Pietinen P. Secular trends in body mass index by birth cohort in eastern Finland from 1972 to 1997. Int J Obes Relat Metab Disord 2001; 25:727-34.

29. Dey DK, Rothenberg E, Sundh V, Bosaeus I, Steen B. Height and body weight in elderly adults: a 21 year population study on secular trends and related factors in 70-year-olds. J Gerontol A Biol Sci Med Sci 2001; 56:M780-4.

30. Cabrera C, Wilhelmson K, Allebeck P, Wedel H, Steen B, Lissner L. Cohort differences in obesityrelated health indicators among 70 -year olds with special reference to gender and education. Eur J Epidemiol 2003; 18:883-90.

31. WHO Expert Committee on Physical Status. The use and interpretation of anthropometry physical status: the use and interpretation of anthropometry: report of a WHO Expert Committee. Geneva: World Health Organization; 1995.

32. Freitas MPD, Loyola Filho AI, Lima-Costa MF. Birth cohort differences in cardiovascular risk factors in a Brazilian population of older elderly: the Bambuí Cohort Study of Aging (1997 and 2008). Cad Saúde Pública 2011; 27 Suppl 3:S409-17.

Submitted on $07 /$ Dec/2010

Final version resubmitted on 16/Apr/2011 Approved on 05/May/2011 